\title{
Stability studies of lincomycin hydrochloride in aqueous solution and intravenous infusion fluids
}

This article was published in the following Dove Press journal:

Drug Design, Development and Therapy

7 March 2016

Number of times this article has been viewed

\section{Petra Czarniak \\ Michael Boddy \\ Bruce Sunderland \\ Jeff $D$ Hughes}

School of Pharmacy, Curtin University, Perth, WA, Australia

Correspondence: Petra Czarniak School of Pharmacy, Curtin University, Kent Street, Bentley, Perth, WA 6102, Australia

Tel +6I 892667419

Fax +6I 892662769

Email p.czarniak@curtin.edu.au
Purpose: The purpose of this study was to evaluate the chemical stability of Lincocin ${ }^{\circledR}$ (lincomycin hydrochloride) in commonly used intravenous fluids at room temperature $\left(25^{\circ} \mathrm{C}\right)$, at accelerated-degradation temperatures and in selected buffer solutions.

Materials and methods: The stability of Lincocin ${ }^{\circledR}$ injection (containing lincomycin $600 \mathrm{mg} / 2 \mathrm{~mL}$ as the hydrochloride) stored at $25^{\circ} \mathrm{C} \pm 0.1^{\circ} \mathrm{C}$ in sodium lactate (Hartmann's), $0.9 \%$ sodium chloride, $5 \%$ glucose, and $10 \%$ glucose solutions was investigated over 31 days. Forced degradation of Lincocin ${ }^{\circledR}$ in hydrochloric acid, sodium hydroxide, and hydrogen peroxide was performed at $60^{\circ} \mathrm{C}$. The effect of $\mathrm{pH}$ on the degradation rate of lincomycin hydrochloride stored at $80^{\circ} \mathrm{C}$ was determined.

Results: Lincomycin hydrochloride was found to maintain its shelf life at $25^{\circ} \mathrm{C}$ in sodium lactate (Hartmann's) solution, $0.9 \%$ sodium chloride solution, $5 \%$ glucose solution, and $10 \%$ glucose solution, with less than 5\% lincomycin degradation occurring in all intravenous solutions over a 31-day period. Lincomycin hydrochloride showed less rapid degradation at $60^{\circ} \mathrm{C}$ in acid than in basic solution, but degraded rapidly in hydrogen peroxide. At all $\mathrm{pH}$ values tested, lincomycin followed first-order kinetics. It had the greatest stability near $\mathrm{pH} 4$ when stored at $80^{\circ} \mathrm{C}$ (calculated shelf life of 4.59 days), and was least stable at $\mathrm{pH} 2$ (calculated shelf life of 0.38 days).

Conclusion: Lincocin $^{\circledR}$ injection was chemically found to have a shelf life of at least 31 days at $25^{\circ} \mathrm{C}$ when added to sodium lactate (Hartmann's) solution, $0.9 \%$ sodium chloride solution, $5 \%$ glucose solution, and $10 \%$ glucose solution. Solutions prepared at approximately $\mathrm{pH} 4$ are likely to have optimum stability.

Keywords: lincomycin, stability, $\mathrm{pH}$, intravenous fluids, IV additives

\section{Introduction}

Lincomycin is a naturally occurring lincosamide antibiotic obtained as a fermentation product of Streptomyces lincolnensis var. lincolnensis. It has a spectrum of activity against Gram-positive bacteria and most anaerobes, but not Gram-negative aerobes. ${ }^{1}$ Its action may be bactericidal or bacteriostatic, dependent on the concentration of the drug attained at the site of infection and the susceptibility of the infecting organism. ${ }^{2}$ It is indicated for the treatment of serious infections due to susceptible strains of Gram-positive aerobes, such as staphylococci, streptococci, and pneumococci, and is generally reserved for patients who are allergic to penicillin. ${ }^{3}$

In Australia, lincomycin is only available as a solution for injection (600 $\mathrm{mg}$ in $2 \mathrm{~mL}$ ), and is the only parenteral lincosamide where the cost is subsidized by the Pharmaceutical Benefits Scheme. ${ }^{4}$ Intravenous (IV) doses are administered on the basis of $1 \mathrm{~g} \mathrm{Lincocin}{ }^{\circledR}$ diluted in not less than $100 \mathrm{~mL}$ of an appropriate solution and infused over a period of not less than 1 hour to avoid severe cardiopulmonary reactions. ${ }^{3}$ Infusion solutions reported to be physically compatible with Lincocin ${ }^{\circledR}$ 
include glucose 5\% solution, glucose $10 \%$ solution, sodium chloride $0.9 \%+$ glucose $5 \%$ solution, sodium chloride $0.9 \%+$ glucose $10 \%$ solution, compound sodium lactate solution, sodium lactate 1/6 molar solution, and dextran 70 solution. ${ }^{3}$ However, according to the Monthly Index of Medical Specialities, "compatibility determinations of lincomycin in these IV fluids are physical observations only and not chemical determinations. Adequate clinical evaluation of the safety and efficacy of these combinations has not been performed", ${ }^{2}$ although stability for 24 hours in dextrose $5 \%$ solution, dextrose $10 \%$ solution, dextrose $5 \%$ in sodium chloride $0.9 \%$ solution, and sodium chloride $0.9 \%$ solution has been reported by the American Society of Health-System Pharmacists. ${ }^{5}$ A dose of $600 \mathrm{mg}$ in a $500 \mathrm{~mL}$ infusion solution provides therapeutic levels for 14 hours. $^{3}$

Few studies on the chemical stability of lincomycin are available in the literature. ${ }^{6,7}$ However, there may be instances where prolonged storage of lincomycin reconstituted in an IV solution is required. For example, in cases of rural or remote administration sites, several days' supply of reconstituted lincomycin in IV solutions may be needed, or in the "hospital in the home" setting, it may be necessary to store reconstituted lincomycin in IV solution for several days.

The purpose of this study was to evaluate the chemical stability of Lincocin ${ }^{\circledR}$ (lincomycin hydrochloride) over a 1 -month period in commonly used IV fluids, including glucose $5 \%$ solution, glucose $10 \%$ solution, sodium lactate (Hartmann's) solution, and sodium chloride $0.9 \%$ solution at room temperature $\left(25^{\circ} \mathrm{C}\right)$ and in various buffer solutions at $80^{\circ} \mathrm{C}$.

\section{Materials and methods Materials}

Lincocin ${ }^{\circledR}$ injection solution containing lincomycin $600 \mathrm{mg} /$ $2 \mathrm{~mL}$ as the hydrochloride and benzyl alcohol $9.45 \mathrm{mg} / \mathrm{mL}$ (batch number G47185, expiry November 2013; Pfizer Inc, New York, NY, USA), 0.9\% sodium chloride solution (batch number S58R4, expiry June 2015; Baxter International Inc, Deerfield, IL, USA), glucose monohydrate 5\% solution (batch number 12186410, expiry April 2015; B Braun Melsungen AG, Melsungen, Germany), glucose monohydrate 10\% solution (batch number 14DC7301, expiry March 2015; Fresenius SE and Co KGaA, Bad Homburg, Germany), and sodium lactate (Hartmann's solution, batch number 122358143, expiry May 2015; B Braun) were obtained commercially. Pure analytical grade lincomycin hydrochloride monohydrate - Vetranal $^{\mathrm{TM}}$ analytical standard (lot SZB8329XV, expiry November 24, 2014; Sigma-Aldrich Co,
St Louis, MO, USA) - was also obtained commercially. High-performance liquid chromatography (HPLC) mobilephase components, including acetonitrile, were HPLC grade. Water was obtained from a Milli-Q ultrapure water system, (EMD Millipore, Billerica, MA, USA) consisting of a fourbowl ultrapure cartridge kit with a conductivity of $0.05 \mu \mathrm{S}$. Measurements of $\mathrm{pH}$ were carried out at room temperature using a digital pH meter (model HI8519N; Hanna Instruments Inc, Woonsocket, RI, USA), which was calibrated with standard buffer solutions.

A pH 2 solution was prepared from $1 \mathrm{M}$ hydrochloric acid, $\mathrm{pH} 3.1$ buffer solution was prepared from anhydrous citric acid and sodium hydroxide, $\mathrm{pH} 4$ acetate-buffer solution was prepared from acetic acid and sodium hydroxide, and pH 6.1 and 8 phosphate-buffer solutions were prepared from orthophosphoric acid and sodium hydroxide. All were adjusted to an ionic strength of 0.5 using sodium chloride.

\section{Preparation of solutions}

With an aseptic technique, $0.4 \mathrm{~mL}$ Lincocin $^{\circledR}$ (lincomycin hydrochloride) was transferred with sterile plastic syringes and stainless steel needles from the original vial to clear-glass volumetric flasks sealed with polypropylene stoppers and brought to $200 \mathrm{~mL}$ with either sodium lactate (Hartmann's) solution, $0.9 \%$ sodium chloride solution, $5 \%$ glucose solution, or $10 \%$ glucose solution. The flasks were stored at $25^{\circ} \mathrm{C} \pm 0.1^{\circ} \mathrm{C}$ in a controlled-temperature water bath under standard laboratory lighting. After agitation, two $5 \mathrm{~mL}$ samples were immediately removed from each volumetric flask and evaluated at time 0 (control), then on day 1 (ie, after 24 hours), 4, 7, 11, 14, 24, and 31. Each sample was analyzed three times by HPLC and the overall mean determined. In addition, one $5 \mathrm{~mL}$ sample was used neat to test $\mathrm{pH}$.

To determine the effect of $\mathrm{pH}$ on the degradation rate of lincomycin hydrochloride, $0.6 \mathrm{mg} / \mathrm{mL}$ lincomycin hydrochloride was prepared at $\mathrm{pH} 2,3.1,4,6.1$, and 8, and stored at $80^{\circ} \mathrm{C}$ (water bath $\pm 0.2^{\circ} \mathrm{C}$ ). Prior to HPLC analysis, each $\mathrm{pH}$ measurement was noted precisely after 10 minutes using a stopwatch.

\section{Assay of lincomycin hydrochloride}

Lincomycin hydrochloride concentrations were determined using chromatographic variables adapted from a reversephase HPLC assay from Catena et al. ${ }^{8}$ HPLC analysis was performed using an HPLC pump (501; Waters Corporation, Milford, MA, USA) connected to a Rheodyne ${ }^{\circledR}$ model 7125 syringe loading sample injector with $20 \mu \mathrm{L}$ sample loop (Sigma-Aldrich), an ultraviolet detector (484 tunable 
absorbance detector; Waters), and a Hewlett-Packard HP 3396 series II integrator/printer. An Apollo C18 (150×4.6 mm, particle size $5 \mu \mathrm{m}$ ) reverse-phase HPLC column was used in conjunction with a reverse-phase guard column. All operations were carried out under ambient conditions.

Samples were eluted isocratically with a mobile phase consisting of $8 \%$ acetonitrile in $50 \mathrm{mM}$ aqueous phosphoric acid adjusted to $\mathrm{pH} 3$ and a flow rate of $1.5 \mathrm{~mL} / \mathrm{min}$. Detection was performed at $220 \mathrm{~nm}$. The retention time for lincomycin hydrochloride was approximately 11.7 minutes.

The method used to assay lincomycin hydrochloride was validated using standards of $\operatorname{Lincocin}^{\circledR}$ solution of $0.1,0.2$, $0.3,0.4,0.5,0.6,0.8$, and $1 \mathrm{mg} / \mathrm{mL}$ to produce a linear relationship $\left(\right.$ area $[$ millions $\left.]=[20.4263 x]+0.3166 ; R^{2}=0.9993\right)$. The linearity of the detector response for a range of pure analytical grade lincomycin hydrochloride monohydrate concentrations $(0.1,0.2,0.4,0.6,0.8$, and $1 \mathrm{mg} / \mathrm{mL})$ was determined (area [millions] $=17.832 x+0.2457 ; R^{2}=0.9999$ ) to validate the reverse-phase HPLC method and to determine the amount of lincomycin in a freshly prepared $0.6 \mathrm{mg} / \mathrm{mL}$ lincomycin hydrochloride sample using Lincocin ${ }^{\circledR}$ injection. For each of the standards, samples were injected into the HPLC system three times and the mean value determined. Intraday and interday coefficients of variation of the $0.6 \mathrm{mg} / \mathrm{mL}$ lincomycin hydrochloride solution were $0.63 \%$.

Forced degradation of $0.6 \mathrm{mg} / \mathrm{mL}$ Lincocin ${ }^{\circledR}$ was performed by heating solutions at $60^{\circ} \mathrm{C}$ in a water bath each in $0.1 \mathrm{M}$ hydrochloric acid and $0.1 \mathrm{M}$ sodium hydroxide for 7 days, and also by exposing the drug solution to $3 \%$ hydrogen peroxide for 60 minutes. Initial lincomycin hydrochloride concentrations $(t=0)$ in the samples were defined as $100 \%$, and all subsequent sample concentrations were expressed as a percentage of the initial concentration. Lincomycin hydrochloride was defined as stable if not less than $90 \%$ of the initial drug concentration remained in the prepared samples. The British Pharmacopoeia and US Pharmacopoeia specifications for the content of lincomycin in lincomycin injection solution are $92.5 \%-107.5 \%$ and $90 \%-120 \%$, respectively. ${ }^{9,10}$

\section{Results}

\section{Forced degradation}

There was no interference of any degradation-product peaks with the peak for intact lincomycin. Lincomycin hydrochloride showed less rapid degradation in acid than in base solutions, with $48.8 \%$ lincomycin remaining in the acid solution after 7 days compared to $8 \%$ remaining in the basic solution after the same time. Lincomycin hydrochloride was found to degrade rapidly in 3\% hydrogen peroxide over 60 minutes.
No peak remained at the retention time for intact lincomycin. When the logarithm of the peak area was plotted against time, the following linear relationship was produced:

$$
\log _{10} \text { peak area }=-(0.03968 \times \text { hours })+7.0225
$$

with a coefficient of determination $\left(R^{2}\right)$ of 0.98333 .

\section{HPLC assay}

The calibration curve of pure analytical grade lincomycin hydrochloride monohydrate was used to determine the amount of lincomycin in the $0.6 \mathrm{mg} / \mathrm{mL}$ lincomycin hydrochloride sample prepared from Lincocin ${ }^{\circledR}$, and was found to contain $0.629 \mathrm{mg} / \mathrm{mL}$ lincomycin. This was equivalent to $104.9 \%$ of the labeled amount. Therefore, the calculated quantity of lincomycin in Lincocin ${ }^{\circledR}$ injections (104.9\%) met the specifications of the British Pharmacopoeia 2014. ${ }^{9}$

HPLC analysis for lincomycin in the presence of degradation products was achieved with $8 \%$ acetonitrile and $92 \%$ water, with a retention time for lincomycin of 11.7 minutes, approximately 5.2 and 8.3 minutes for degradation products, and 11 minutes for lincomycin B (Figure 1).

\section{Intravenous additive solutions}

One-month stability testing of lincomycin hydrochloride at $25^{\circ} \mathrm{C}$ found that it was stable in sodium lactate (Hartmann's) solution, $0.9 \%$ sodium chloride solution, $5 \%$ glucose solution, and $10 \%$ glucose solution, with less than $5 \%$ lincomycin degradation in all IV solutions over a 31-day period and thus a shelf life of at least 31 days (Table 1).

\section{Buffer solutions}

The results for the accelerated stability testing of lincomycin in buffer solutions at $\mathrm{pH} 2,3.1,4,6.1$, and 8 showed that lincomycin followed first-order kinetics at all $\mathrm{pH}$ values tested. It had the greatest stability near $\mathrm{pH} 4$ when stored at $80^{\circ} \mathrm{C}$, with a calculated shelf life of 4.59 days. It was least stable at $\mathrm{pH} 2$, with a calculated shelf life of 0.38 days. The calculated first-order rate constants and shelf-life values of lincomycin at each $\mathrm{pH}$ value tested are summarized in Table 2. All kinetic runs were examined to achieve a $15 \%$ or greater loss of lincomycin.

Figure 2, which shows a $\log _{k}: \mathrm{pH}$ profile of lincomycin, also indicates that lincomycin was most stable near $\mathrm{pH} 4$ with respect to the $\mathrm{pH}$ values tested. Since lincomycin is a basic compound in which the tertiary amino group has a $\mathrm{pK}_{\mathrm{a}}$ of 7.6 at low $\mathrm{pH}$ (ie, $\mathrm{pH} 2-3$ ), ${ }^{11}$ it undergoes acid-catalyzed degradation of the protonated form. At higher $\mathrm{pH}$ values, from 


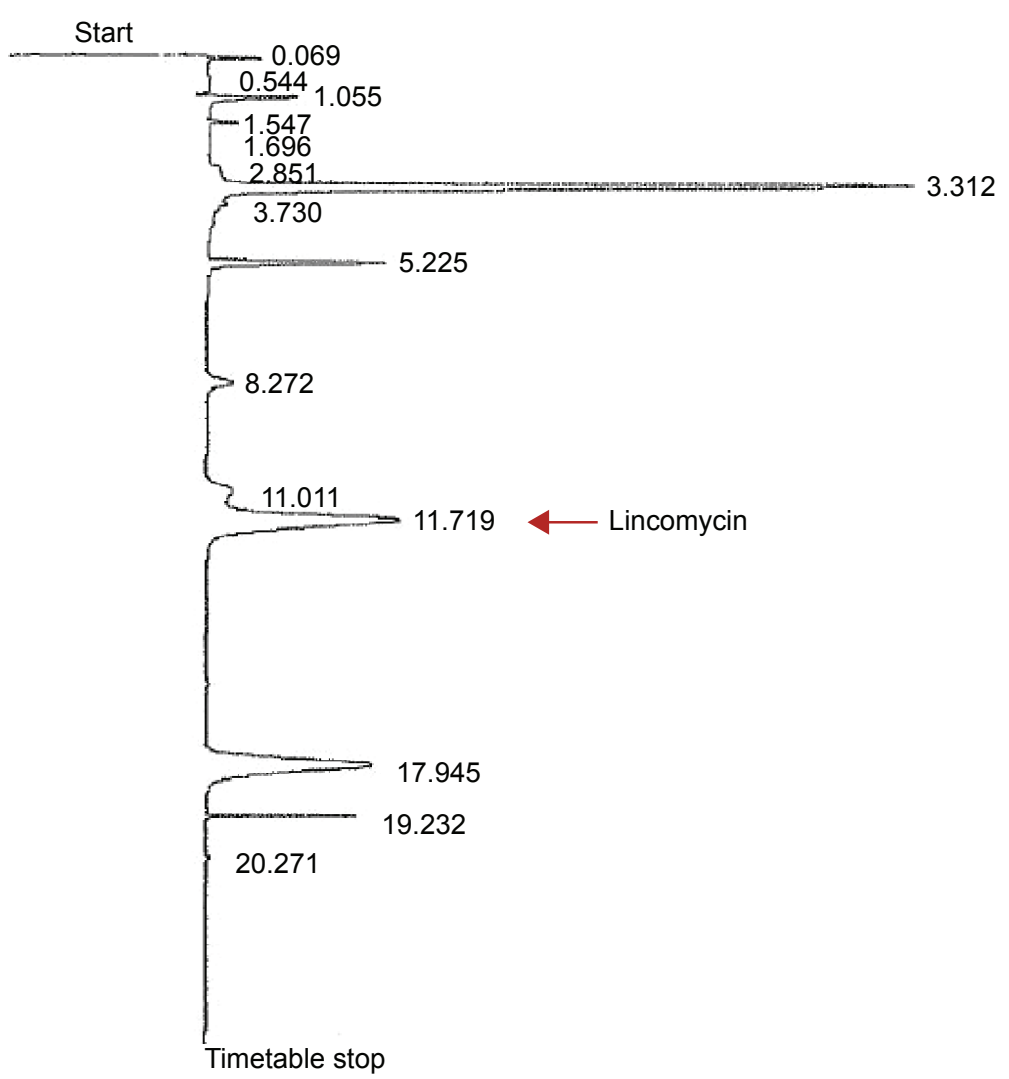

Figure I Evidence of lincomycin breakdown products when $0.6 \mathrm{mg} / \mathrm{mL}$ lincomycin hydrochloride was prepared in $0.1 \mathrm{M} \mathrm{HCl}$ and stored at $60^{\circ} \mathrm{C}$ for 432 hours. Notes: The lincomycin peak occurred at 1 I.719 minutes and the peak at II.0II minutes is lincomycin B. The benzyl alcohol peak occurred at I7.945 minutes.

pH 6.1-8, there is some hydroxyl ion catalysis possibly limited by the slow reaction of the unionized species occurring in the higher $\mathrm{pH}$ range.

\section{Discussion}

This study has provided important practical chemical stability data to facilitate the administration of lincomycin in commonly used IV fluids. The data show lincomycin to be a relatively stable antibiotic, with a shelf life of at least 31 days at room temperature $\left(25^{\circ} \mathrm{C}\right)$ in all IV solutions tested. These solutions were stored in sealed clear-glass flasks. Stability in IV bags could be dependent on the specific bag selected. This would enable the aseptic preparation of solutions for storage in hospital or home settings. Although the shelf life was assigned on the initial loss of $10 \%$ lincomycin, it is also notable that all solutions conformed with the British

Table I Percentage of lincomycin hydrochloride retained (initial concentration $0.6 \mathrm{mg} / \mathrm{mL}$ ) in four intravenous solutions stored at $25^{\circ} \mathrm{C} \pm 0.1^{\circ} \mathrm{C}$ over 744 hours (3I days)

\begin{tabular}{|c|c|c|c|c|c|c|c|c|c|c|c|c|}
\hline \multirow{2}{*}{$\begin{array}{l}\text { Time } \\
\text { (hours) }\end{array}$} & \multicolumn{3}{|c|}{ Hartmann's solution } & \multicolumn{3}{|c|}{$0.9 \%$ sodium chloride solution } & \multicolumn{3}{|c|}{$5 \%$ glucose solution } & \multicolumn{3}{|c|}{$10 \%$ glucose solution } \\
\hline & $\mathrm{pH}$ & $\begin{array}{l}\text { Mean } \\
\text { peak area }\end{array}$ & $\begin{array}{l}\text { Percentage } \\
\text { of baseline } \\
\text { AUC }\end{array}$ & $\mathrm{pH}$ & $\begin{array}{l}\text { Mean } \\
\text { peak area }\end{array}$ & $\begin{array}{l}\text { Percentage } \\
\text { of baseline } \\
\text { AUC }\end{array}$ & $\mathrm{pH}$ & $\begin{array}{l}\text { Mean } \\
\text { peak area }\end{array}$ & $\begin{array}{l}\text { Percentage } \\
\text { of baseline } \\
\text { AUC }\end{array}$ & $\mathrm{pH}$ & $\begin{array}{l}\text { Mean } \\
\text { peak area }\end{array}$ & $\begin{array}{l}\text { Percentage } \\
\text { of baseline } \\
\text { AUC }\end{array}$ \\
\hline 0 & 6.28 & $6,297,749$ & 100 & 5.87 & $6,426,908$ & 100 & 3.49 & $6,569,197$ & 100 & 3.73 & $6,427,563$ & 100 \\
\hline 24 & 6.26 & $6,141,936$ & 97.5 & 5.75 & $6,193,777$ & 96.4 & 3.51 & $6,245,656$ & 95.1 & 3.67 & $6,345,394$ & 98.7 \\
\hline 96 & 6.22 & $6,298,190$ & 100 & 5.80 & $6,384,620$ & 99.3 & 3.52 & $6,435,503$ & 98 & 3.73 & $6,429,390$ & 100 \\
\hline 168 & 6.23 & $6,27 I, 727$ & 99.6 & 5.87 & $6,34 I, 349$ & 98.7 & 3.60 & $6,366,680$ & 96.9 & 3.65 & $6,364,180$ & 99 \\
\hline 264 & 6.30 & $6,307,764$ & 100.2 & 5.97 & $6,429,204$ & 100 & 3.53 & $6,474,652$ & 98.6 & 3.61 & $6,462,238$ & 100.5 \\
\hline 336 & 6.27 & $6,409,389$ & 101.8 & 5.75 & $6,442,4 I I$ & 100.2 & 3.50 & $6,250,465$ & 95.1 & 3.62 & $6,312,479$ & 98.2 \\
\hline 575.5 & 6.34 & $6,168,075$ & 97.9 & 5.80 & $6,345,487$ & 98.7 & 3.37 & $6,424,328$ & 97.8 & 3.55 & $6,28 I, 076$ & 97.7 \\
\hline 744 & 6.44 & $6,266,224$ & 99.5 & 5.79 & $6,263,480$ & 97.5 & 3.45 & $6,458,256$ & 98.3 & 3.52 & $6,395,738$ & 99.5 \\
\hline
\end{tabular}

Abbreviation: AUC, area under the curve. 
Table 2 Data for lincomycin showing the gradient of the first-order equations, coefficient of determination, first-order rate constant, and shelf-life values obtained at $80^{\circ} \mathrm{C}$

\begin{tabular}{|c|c|c|c|c|c|c|c|}
\hline $\mathrm{pH}$ & Graph type & $\begin{array}{l}\text { Gradient } \\
\left(m \times 10^{-3}\right)\end{array}$ & $\begin{array}{l}\text { Error } \\
\left(\times 10^{-5} \pm 2 \text { SD }\right)\end{array}$ & $\begin{array}{l}\text { Coefficient of } \\
\text { determination }\left(R^{2}\right)\end{array}$ & $\begin{array}{l}k \\
\left(\times 10^{-3} \cdot \text { hour }^{-1}\right)\end{array}$ & $t_{90}$ (hours) & $t_{90}$ (days) \\
\hline 2 & $\log _{10}$ peak area & -4.94 & 6.048 & 0.99836 & $\mathrm{II} .4$ & 9.23 & 0.38 \\
\hline 3.1 & $\log _{10}$ peak area & -0.72 & 5.118 & 0.97058 & 1.66 & 63.32 & 2.64 \\
\hline 4 & $\log _{10}$ peak area & -0.41 & 4.144 & 0.94323 & 0.95 & 110.2 & 4.59 \\
\hline 6.1 & $\log _{10}$ peak area & -1.75 & 8.884 & 0.98484 & 4.03 & 26.05 & 1.09 \\
\hline 8 & $\log _{10}$ peak area & -2.14 & 6.488 & 0.99543 & 4.93 & 21.31 & 0.89 \\
\hline
\end{tabular}

Abbreviations: $S D$, standard deviation; $t_{90}$, time for drug concentration to decrease to $90 \%$.

Pharmacopoeia specification of $92.5 \%-107.5 \%$ and the US Pharmacopoeia requirement of $90 \%-120 \%$ content of lincomycin as the hydrochloride. It is stated that Lincocin ${ }^{\mathbb{R}}$ (which contains lincomycin hydrochloride) can be administered by direct intramuscular injection every 12-24 hours at a dose of $10 \mathrm{mg} / \mathrm{kg} /$ day. Alternatively, IV doses can be administered on the basis of $1 \mathrm{~g}$ Lincocin $^{\circledR}$ diluted in not less than $100 \mathrm{~mL}$ of appropriate IV solution, including sodium lactate solution, $0.9 \%$ sodium chloride solution, $5 \%$ glucose solution, and $10 \%$ glucose solution, and infused over at least 1 hour. ${ }^{3}$ Current stability information on lincomycin in these IV solutions is limited to the compatibility of lincomycin in these IV fluids, which are physical determinations rather than chemical determinations. ${ }^{3}$ Physical compatibility has been reported only for 24 hours at room temperature. ${ }^{2}$

An initial investigation was also carried out to ensure that the Lincocin ${ }^{\circledR}$ sample used in the study met the British Pharmacopoeia 2014 specifications for the content of lincomycin in the lincomycin hydrochloride injection. The amount of lincomycin base in a $0.6 \mathrm{mg} / \mathrm{mL}$ lincomycin sample prepared from Lincocin ${ }^{\circledR}$ was found to contain $0.629 \mathrm{mg} / \mathrm{mL}$

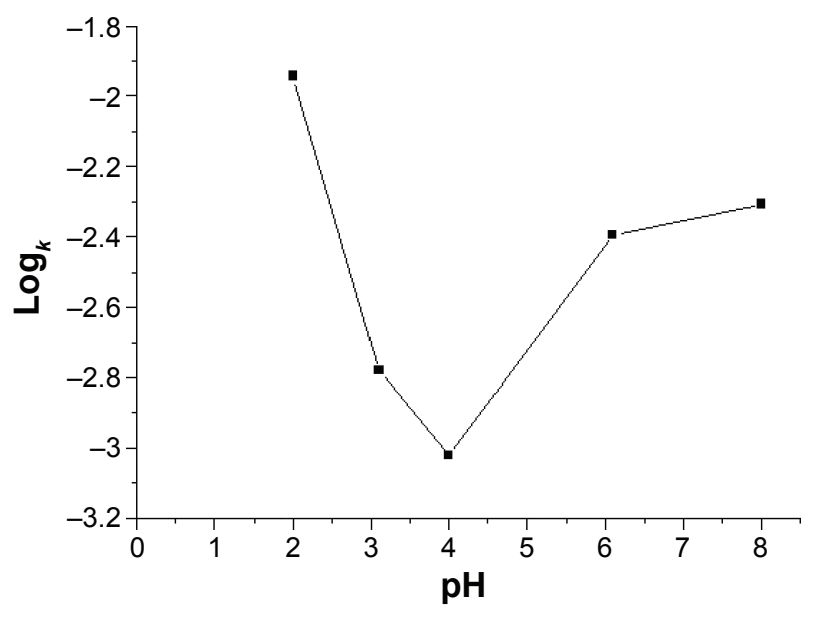

Figure $2 \log _{k}: \mathrm{pH}$ profile of lincomycin $0.6 \mathrm{mg} / \mathrm{mL}$ as lincomycin hydrochloride at $80^{\circ} \mathrm{C}$ in selected buffers $(\mathrm{I}=0.5)$. lincomycin, equivalent to $104.9 \%$ of the stated amount. Therefore, the calculated quantity of lincomycin in Lincocin ${ }^{\circledR}$ injection (104.9\%) met the specifications of both the British Pharmacopoeia and US Pharmacopoeia. ${ }^{9,10}$

Forced-degradation studies examined the degradation of $0.6 \mathrm{mg} / \mathrm{mL}$ lincomycin in $0.1 \mathrm{M}$ hydrochloric acid solution, $0.1 \mathrm{M}$ sodium hydroxide solution, and 3\% hydrogen peroxide solution at $60^{\circ} \mathrm{C}$. These showed that lincomycin degradation occurred most rapidly in hydrogen peroxide, suggesting that lincomycin hydrochloride readily undergoes oxidation. Less rapid degradation was observed in strong acid and base solutions after 7 days. A study investigating the stability of $0.4 \%$ lincomycin hydrochloride in $0.1 \mathrm{~N}$ hydrochloric acid solution at $37^{\circ} \mathrm{C}$ and $70^{\circ} \mathrm{C}$ reported that lincomycin showed no degradation for at least 48 hours at $37^{\circ} \mathrm{C}$ and slow degradation (half-life 39 hours) at $70^{\circ} \mathrm{C} .{ }^{6}$

In a study investigating the stability of the closely structurally related clindamycin in 5\% dextrose and $0.9 \%$ sodium chloride at $4{ }^{\circ} \mathrm{C}$ and room temperature $\left(23^{\circ} \mathrm{C}\right)$ over 21 days, researchers reported that the degradation of clindamycin was slow, with less than $5 \%$ loss occurring at various concentrations of clindamycin in each diluent and at each temperature. This is similar to the findings for lincomycin in the current study, although a single concentration $(0.6 \mathrm{mg} / \mathrm{mL})$ was used in each IV solution. ${ }^{7}$

Degradation studies of lincomycin hydrochloride at $80^{\circ} \mathrm{C}$ at $\mathrm{pH} 2,3,4,6.1$, and 8 followed first-order kinetics and the rate constant was lowest near $\mathrm{pH} 4$, with a calculated shelf life of 4.59 days. It was least stable at $\mathrm{pH} 2$, with a calculated shelf life of 0.38 days. The $\mathrm{pH}$-rate profile shows specific acid catalysis of the protonated species at low $\mathrm{pH}$ values; however, the hydroxide ion catalyses of lincomycin showed a slowing in reaction rate as the molecular species increased in concentration.

This finding would indicate that infusions prepared at approximately $\mathrm{pH} 4$ would have the greatest potential stability, making the $5 \%$ or $10 \%$ glucose solutions 
having optimum $\mathrm{pH}$ values regarding long-term stability. Benzyl alcohol was included in Lincocin ${ }^{\circledR}$; however, in the preparation of the infusions for this study, it was diluted to $0.0189 \mathrm{mg} / \mathrm{mL}$. It would not be expected that its inclusion as a preservative in small-volume solutions would influence the stability data reported in this study.

\section{Conclusion}

Lincocin ${ }^{\circledR}$ injection solution containing lincomycin hydrochloride $300 \mathrm{mg} / \mathrm{mL}$ and benzyl alcohol $9.45 \mathrm{mg} / \mathrm{mL}$ was found to retain its shelf life at $25^{\circ} \mathrm{C}$ when added to sodium lactate (Hartmann's) solution, $0.9 \%$ sodium chloride solution, 5\% glucose solution, and $10 \%$ glucose solutions for at least 31 days.

Degradation studies of lincomycin hydrochloride at $80^{\circ} \mathrm{C}$ at various $\mathrm{pH}$ values showed that lincomycin was most stable near $\mathrm{pH} 4$, with a calculated shelf life of 4.59 days, and was least stable at $\mathrm{pH} 2$, with a calculated shelf life of 0.38 days. These data would suggest solutions prepared at approximately pH 4 are likely to have optimum stability.

\section{Disclosure}

The authors report no conflicts of interest in this work.

\section{References}

1. Greenwood D. Lincosamines. In: Finch RG, Greenwood D, Norrby SR, Whitley RJ, editors. Antibiotic and Chemotherapy: Anti-infective Agents and Their Use in Therapy. Edinburgh: Saunders Elsevier; 2010:272-275.
2. Lincocin ${ }^{\circledR}$ [product information]. Australian Government Department of Health. Therapeutics Goods Administration. Available from: https:// www.ebs.tga.gov.au/ebs/picmi/picmirepository.nsf/pdf?OpenAgent=\& $\mathrm{id}=$ CP-2010-PI-05409-3\&d=2016020516114622412. Accessed February 5, 2016.

3. Monthly Index of Medical Specialities (eMIMS). Lincocin. 2015. Available from: https://www.mimsonline.com.au.dbgw.lis.curtin.edu. au/Search/Search.aspx. Accessed December 2, 2015.

4. Australian Government Department of Health. Schedule of Pharmaceutical Benefits: Effective 1 June-30 June 2015. Canberra: Commonwealth of Australia; 2015. Available from: http://www.pbs. gov.au/publication/schedule/2015/06/2015-06-01-general-schedule. pdf. Accessed December 2, 2015.

5. American Society of Health-System Pharmacists. Handbook on Injectable Drugs. 18th ed. Bethesda (MD): ASHP; 2014.

6. Forist AA, Brown LW, Royer ME. Acid stability of lincomycin. J Pharm Sci. 1965;54(3):476-477.

7. Walker SE, Iazzetta J, Law S, Biniecki K. Stability of commonly used antibiotic solutions in an elastomeric infusion device. Can J Hosp Pharm. 2010;63(3):212-224.

8. Catena E, Perez G, Sadaba B, Azanza JR, Campanero MA. A fast reversephase high performance liquid chromatographic tandem mass spectrometry assay for the quantification of clindamycin in plasma and saliva using a rapid resolution package. J Pharm Biomed Anal. 2009;50(4): 649-654.

9. Medicines and Healthcare Products Regulatory Agency. British Pharmacopoeia 2014. London: Stationery Office; 2013.

10. US Pharmacopeial Convention. US Pharmacopeia National Formulary (USP37-NF32). Rockville (MD): US Pharmacopeia National Formulary; 2014.

11. Herr RR, Slomp G. Lincomycin. II. Characterization and gross structure. J Am Chem Soc. 1967;89(10):2444-2447.
Drug Design, Development and Therapy

\section{Publish your work in this journal}

Drug Design, Development and Therapy is an international, peerreviewed open-access journal that spans the spectrum of drug design and development through to clinical applications. Clinical outcomes, patient safety, and programs for the development and effective, safe, and sustained use of medicines are a feature of the journal, which

\section{Dovepress}

has also been accepted for indexing on PubMed Central. The manuscript management system is completely online and includes a very quick and fair peer-review system, which is all easy to use. Visit http://www.dovepress.com/testimonials.php to read real quotes from published authors. 